\title{
Progressive and regressive soil evolution phases in the Anthropocene
}

Manon Bajard, Jérôme Poulenard, Pierre Sabatier, Anne-Lise Develle, Charline GiguetCovex, Jeremy Jacob, Christian Crouzet, Fernand David, Cécile Pignol, Fabien Arnaud

Highlights

- Lake sediment archives are used to reconstruct past soil evolution.

- Erosion is quantified and the sediment geochemistry is compared to current soils.

-We observed phases of greater erosion rates than soil formation rates.

- These negative soil balance phases are defined as regressive pedogenesis phases.

- During the Middle Ages, the erosion of increasingly deep horizons rejuvenated pedogenesis.

\section{Abstract}

Soils have a substantial role in the environment because they provide several ecosystem services such as food supply or carbon storage. Agricultural practices can modify soil properties and soil evolution processes, hence threatening these services. These modifications are poorly studied, and the resilience/adaptation times of soils to disruptions are unknown. Here, we study the evolution of pedogenetic processes and soil evolution phases (progressive or regressive) in response to human-induced erosion from a 4000-year lake sediment sequence (Lake La Thuile, French Alps). Erosion in this small lake catchment in the montane area is quantified from the terrigenous sediments that were trapped in the lake and compared to the soil formation rate. To access this quantification, soil processes evolution are deciphered from soil and sediment geochemistry comparison. Over the last 4000 years, first impacts on soils are recorded at approximately $1600 \mathrm{yr}$ cal. BP, with the erosion of surface horizons exceeding $10 \mathrm{t} \cdot \mathrm{km}^{-2} \cdot \mathrm{yr}^{-1}$. Increasingly deep horizons were eroded with erosion accentuation during the Higher Middle Ages (1400-850 yr cal. BP), reaching $1000 \mathrm{t} \cdot \mathrm{km}^{-2} \cdot \mathrm{yr}^{-1}$, and leading to the remobilization of carbonated and poorly weathered material, hence rejuvenating soil development. Erosion exceeded the soil formation rate and constituted a regression in the development of soils. The tolerable erosion limit is thus defined for erosion from 25 to $30 \mathrm{t} \cdot \mathrm{km}^{-2} \cdot \mathrm{yr}^{-1}$. Beyond this limit, the sustainability of the agroecosystem is limited and ecosystem services decrease. Afterwards, pedogenesis evolved again from progressive (700-300 $\mathrm{yr}$ cal. BP) to regressive (300 yr cal. BP-today) phases. Erosion was less important during the last 700 years than during the Middle Ages but with the same weathering stages, indicating that soils were deeply affected during the Middle-Age and have yet not recovered. Our results highlight the importance of the human factor in the pedogenesis over last millennia and suggest that the studied agro-ecosystem entered the Anthropocene 1400 years ago. 
Abbreviations : E, erosion; V, volume; SF, soil formation; ST, soil thickness; SL, soil loss; TS, terrigenous sediment; SY, sediment yield; DD, dry density (for sediment); BD, bulk density (for soil); $M_{\text {sed, }}$ mass of sediment; $\mathrm{NCIR}$, non-carbonate ignition residue; $\mathrm{OM}$, organic matter; TOC, total organic carbon

Keywords : Pedogenesis; Lake sediment; Erosion; Geochemistry; Human impact; Anthropocene

\section{Introduction}

The intensification of agricultural practices and their increasing pressure on agroecosystems are known to modify soil properties and pedogenetic processes (Matson, 1997, Grieve, 2001, Dupouey et al., 2002 and Bojko and Kabala, 2016). The first evidence of human settlements/agriculture in the Alps dates from the Neolithic period (Martin et al., 2008 and Dotterweich, 2013). The natural evolution of soils was probably disturbed from this period, which began with fire deforestation (Gobet et al., 2003, Colombaroli et al., 2013 and Valese et al., 2014). Indeed, the removal of vegetation cover results in the destabilization of slopes and increased erosion fluxes downstream (Edwards and Whittington, 2001). Nowadays, the triggered loss of soil represents a threat to mountain economies (food supply), the water quality and carbon storage (Pimentel, 2006). The effects of this threat on soil properties, soil quality and ecosystem services from a long-term perspective and the resilience of mountain soils to disruption for a given management are poorly known. A better understanding on how soils function and react to disruptions is crucial to predict their evolution and adapt our management for future generations (Arshad and Martin, 2002).

Pedogenesis results from a succession of processes, which depend on soil the forming factors: climate, relief, living organisms (including humans and their activities), parent material and time (Jenny, 1941). 
This evolution is characterized by different positive and negative phases (Pallmann, 1947; Erhart, 1967; Duchaufour, 1970; Huggett, 1998). Different meanings of regression, including qualitative and quantitative, are possible. The nature of soils can change, such as by rejuvenating, leading to a regression of the pedogenesis state without regressing in terms of depth (Pallmann, 1947; Duchaufour, 1970; Egli and Poulenard, 2016). Erosion is a natural process, and tolerable erosion is necessary to ensure the sustainability of systems. Sustainable management must prevent erosion from exceeding soil formation rate to avoid the regression and degradation of soils (Verheijen et al., 2009; Dotterweich, 2013). Regression can also mean that the gradual evolution of a soil is disrupted during its development and that its degree of evolution regresses (Jäger et al., 2015).

Most of the soils in the Alps initially formed following glacial retreat from bedrock or superficial deposits (Alewell et al., 2015; Jäger et al., 2015; Le Roy et al., 2015). Weathering that was reinforced by vegetation settlement allowed a thin layer of soil to develop and grow. This process can currently be observed and dated from chronosequences that have been studied at the front of glaciers (Huggett, 1998; Egli et al., 2001). These observations of pedogenesis on short time scales (10 to 100 years) can also be observed with long-term field experiments and recent well-dated modifications of land use (Arshad and Martin, 2002; Montagne et al., 2016). The contexts of pristine soils i.e. non-humanaffected soils, are difficult to access at this latitude for comparison. Nonetheless, the study of current soils is necessary to understand their evolution. Current soils work as boundary conditions: they are the final point of their evolution. Soils have a memory and exploitable properties to reconstruct past soils but are not often suitable chronometers because of chemical and physical transfers (Huggett, 1998).

Sediment archives are useful to find old soil footprints and reconstitute their temporal evolution, especially in a context of intense human activities and with long-term perspectives. One of the most prominent and trackable consequences of human practices on the environment is the erosion of soils (Foley, 2005; Pimentel, 2006). Lake sediments can store erosion products, which are thus a component of soils when erosion is active (Edwards and Whittington, 2001; Arnaud et al., 2012). Sediment archives are also relevant to stratigraphically define the Anthropocene (Blum and Eswaran, 2004; Crutzen, 2006; Waters et al., 2016). If changes in the stratigraphy are a consequence of pedogenesis modification (Erhart, 1967), the Anthropocene should be locally defined by the effects of humans on soil evolution. The quantification of erosion from lake sediment sequences has been investigated by several authors (Zolitschka, 1998; Enters et al., 2008; Massa et al., 2012; Foucher et al., 2015), but few studies have attempted to decipher the soil evolution from lake sediments (Mourier et al., 2010; Giguet-Covex et al., 2011; Arnaud et al., 2012; Jäger et al., 2015). This quantification enables us to determine the intensity of the disruption that triggered the loss of soil and the tolerable erosion in the catchment according to the difference from the soil formation rate, which could be a local definition of the Anthropocene (Verheijen et al., 2009; Li et al., 2009; Alewell et al., 2015).

Lake La Thuile, which is located in the French pre-Alps, provides a long sedimentary sequence that spans the entire Late-glacial and Holocene periods. A high-resolution multi-proxy (sedimentological, palynological, and geochemical) analysis of the uppermost $6.2 \mathrm{~m}$ (Bajard et al., 2016) revealed a mainly lacustrine origin for the sediment during the late and mid-Holocene periods (12,000-4000 yr cal. BP), and the forest that was established around the lake prevented erosion on these slopes. The sedimentary filling of the lake during the late Holocene period was mainly a consequence of human-induced erosion in response to landuse changes (Bajard et al., 2016). The first human effects in the landscape were identified ca. $3300 \mathrm{cal}$. BP with a decrease in the forest cover and subsequent slight increase in terrigenous input. Thus, we choose to first focus on the last 12,000 years and then on the last 4000 years by combining both quantitative and qualitative approaches of pedogenetic processes and their resilience to human-induced modifications. Combining analyses of the soils in the catchment and those of lake sediment should enable us to: i) characterize the erosion products in relation to pedogenetic sources, ii) quantify the erosion in terms of the soil thickness and iii) model the soil formation to assess the sustainability of the system.

\section{Materials and methods}

\subsection{Study site}

Lake La Thuile $\left(45^{\circ} 31^{\prime} 50.63^{\prime \prime} \mathrm{N}, 6^{\circ} 3^{\prime} 39.9^{\prime \prime} \mathrm{E}\right)$ is a small lake $\left(0.06 \mathrm{~km}^{2}\right)$ in the montane zone in the southern of the Bauges Massif at $874 \mathrm{~m}$ a.s.l. in the Northern French Alps (Fig. 1a). This lake has an oval shape (approximately $465 \mathrm{~m}$ by $156 \mathrm{~m}$ ), and its maximum depth reaches $8 \mathrm{~m}$. The catchment around the lake rises up to $1209 \mathrm{~m}$ a.s.l. and covers an area of $1.6 \mathrm{~km}^{2}$. Except for the gentle grazed slopes near the lake and the village of La Thuile, most of the catchment area is currently forested (Fig. 1b). The lake is fed by two main temporary streams that flow during snow melt and long rainfalls. The northern stream begins in a small gully area. The lake is of glacial origin and is part of the Lake Bourget catchment through the Leysse River. The climate is temperate, with an annual temperature from 6 to $8^{\circ} \mathrm{C}$ and annual precipitation from 1500 to $1700 \mathrm{~mm}$ (Zamolo, 1980). Rainfall is concentrated in winter. The lake can be ice-covered during cold winters.

The catchment area is mainly underlain by carbonate rocks. Hard micritic limestones (Jurassic Tithonic formation) that consist of massive strata cover the southeastern area of the catchment (Fig. 1c). Intercalations of calcareous formations with Berriasian marls and shales and Valanginian spathic limestones (Geologic map 1/50,000, Montmélian sheet) cover most of the area (Fig. 1c). Quaternary glacial deposits are found in the northwestern area of the catchment and at the outlet of the lake.

The surroundings of the lake are occupied by grasslands and pastures. The northern and eastern sides of the catchment are covered by woodland, with planted resinous trees (Picea abies) to the north and hardwoods elsewhere. Old terraces, maybe as a consequence of hedge, are always visible in the landscape. Old photography from the beginning of the 20th century show that the current meadows replaced cereal cultures and that forest was less extensive at that time with pastures on the upper shores of the lake (Fig. 2).

\subsection{Soil characterization and sampling}

Five soil profiles (THU01, THU02, THU03, THU04 and THU06) and two augers observations (THU05 and THU07) were realized to characterize the major soil types in the catchment (Fig. 1). These profiles were chosen according to their topography, geology and land use to be representative of most soils in the catchment. THU05 developed on a small alluvial fan. Auger observations were performed to confirm the expansion of a given soil unit and to increase the sampling representativeness.

The soil profiles were described by horizons with common descriptors, including color (Munsell Color, 2000), texture, structure, roots, coarse elements, and matrix reaction to an acid solution. The FAO (Food and Agriculture Organization) soil classification (WRB - FAO, 2014) and the Guidelines for soil description (FAO, 2006) were used for horizon and soil denomination (Fig. 3). One sample was collected from each horizon for further laboratory analyses.

\subsection{Sediment sequence and chronology}

An 18-m-long sediment sequence (THU10, IGSN: IEFRA00BB - IGSN codes refer to an open international database, www.geosamples.org) was retrieved from the deepest part of Lake La Thuile and described in Bajard et al. (2016). 


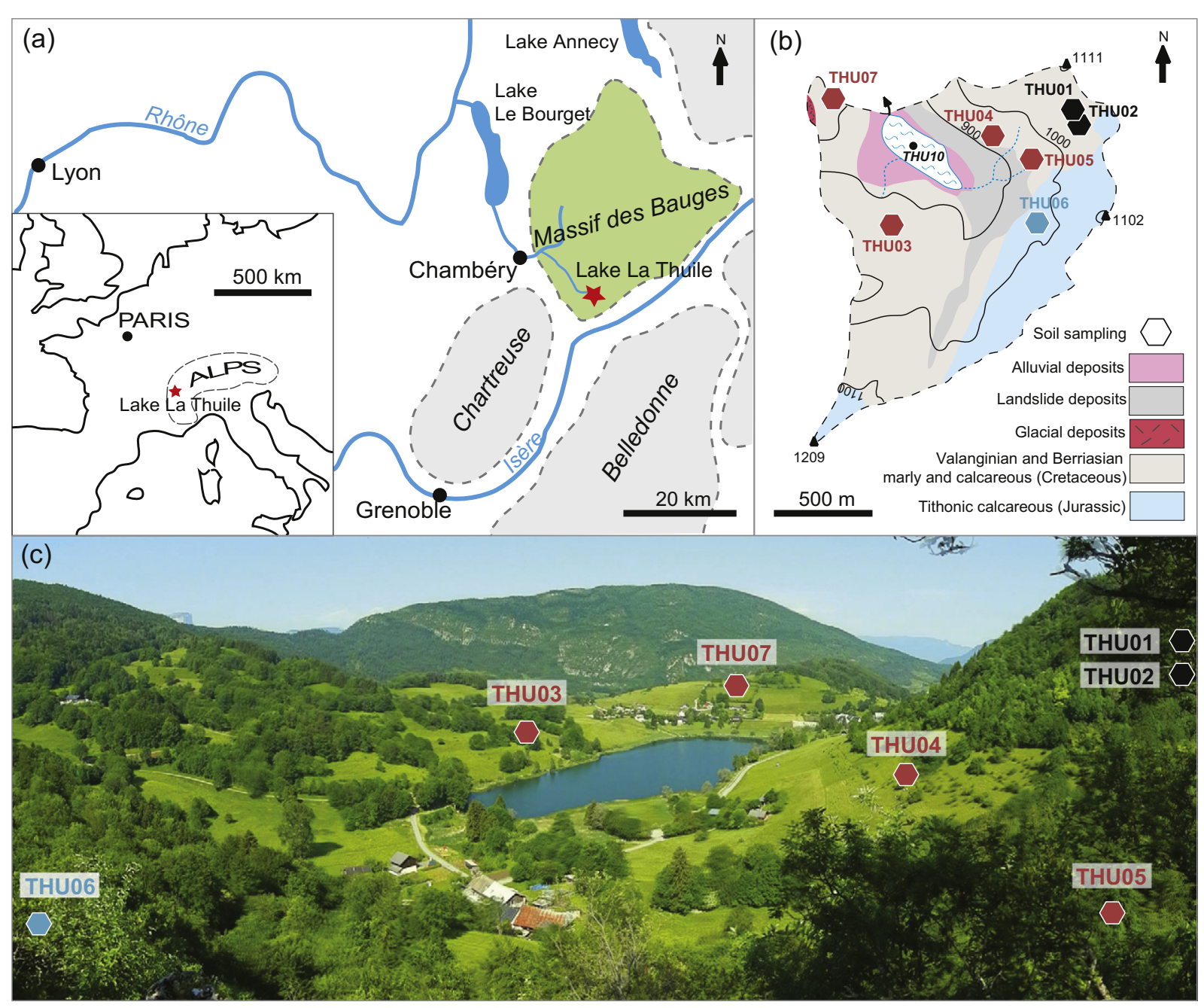

Fig. 1. Location of Lake La Thuile in the Massif des Bauges (a) and the geology (b) and soil sampling sites in its catchment (b, c).

The chronology of the first $6.2 \mathrm{~m}$ of sediment was based on $15{ }^{14} \mathrm{C}$ measurements from terrestrial plant macroremains, short-lived radionuclide measurements and paleomagnetic secular variations (Bajard et al., 2016). The age-depth model which was generated with the $R$ software and the $R$-code package "Clam" version 2.2 (Blaauw, 2010), was adapted with a smooth spline [type $=4$ ] with spar $=0.3$ [smooth] for the modeling. The sedimentation rate (SR) was computed with the "clam" function and a 95\% confidence interval.

The first $6.2 \mathrm{~m}$, which correspond to the Holocene period, were used for the modeling, especially to calculate the cumulative soil loss. The first occurrences of human activity were estimated around $3300 \mathrm{cal}$.
BP from palynological evidence of anthropic taxa and an increase in erosion (Bajard et al., 2016), so the last 4000 cal. BP were more closely studied to focus on the potential human disturbance of soils.

\subsection{Soil and sediment analysis}

Soil samples were dried in the open air and sieved at $2 \mathrm{~mm}$. Around $2 \mathrm{~g}$ of sieved soil were mixed with $10 \mathrm{~mL}$ of water to measure the water $\mathrm{pH}$ of the soil.
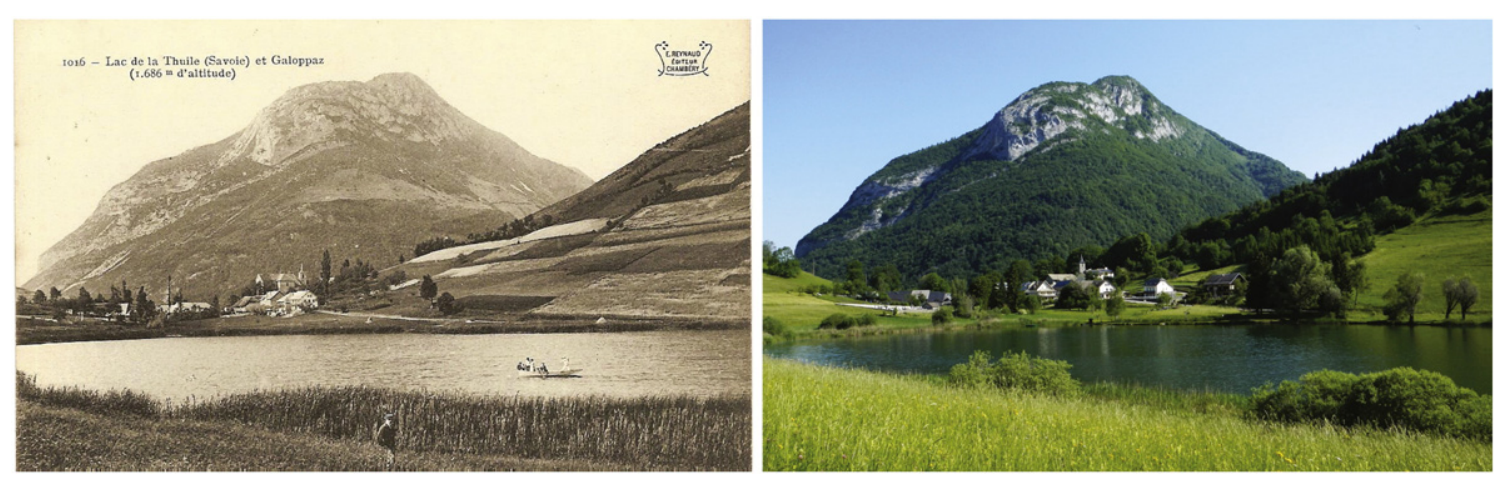

Fig. 2. Soilscape modifications between 1907 and 2015 on the shores of Lake La Thuile. 


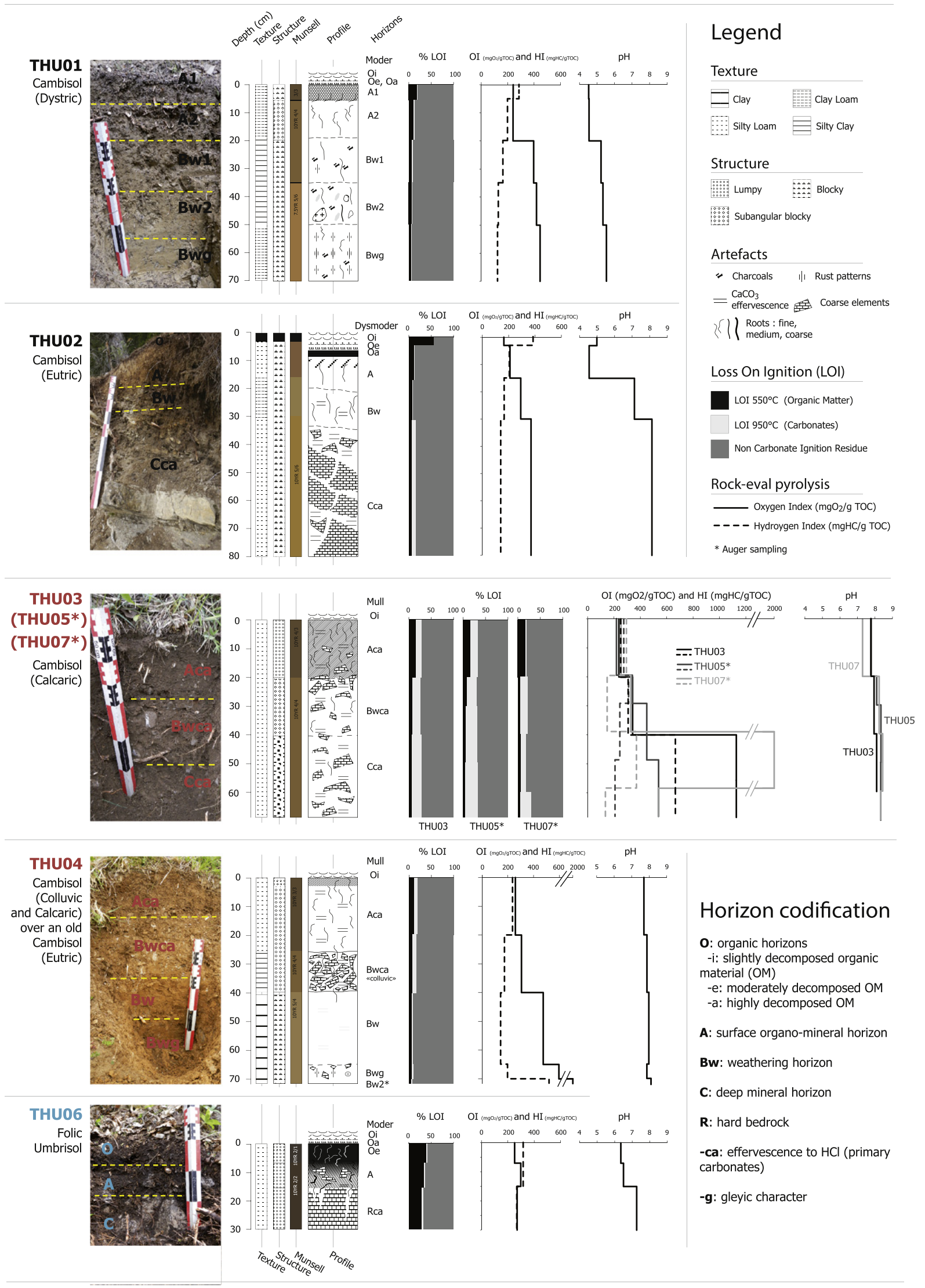

Fig. 3. Pedologic description of the soil profiles (texture, structure, color) with Loss On Ignition, Oxygen Index and pH measurements with horizons, as defined according to the WRB (WRB - FAO, 2014) and the Guidelines for soil description (FAO, 2006). 


\subsubsection{Loss On Ignition (LOI)}

The Loss On Ignition (LOI) was recorded at $550{ }^{\circ} \mathrm{C}$ over $4 \mathrm{~h}$ and $950{ }^{\circ} \mathrm{C}$ over $2 \mathrm{~h}$ both on both the soil and sediment samples following the procedure of Heiri et al. (2001) to estimate the Organic Matter (OM), carbonate and terrigenous contents of the samples. The results for the sediment samples were described in Bajard et al. (2016).

\subsubsection{Organic geochemistry}

The soil and sediment organic matter quality was obtained by using a Rock-Eval RE6 pyrolyser ("Turbo" model, Vinci Technologies (C)) at the ISTO Laboratory in Orléans (Talbot, 1988; Disnar et al., 2003). The Oxygen Index $\left(\mathrm{OI}, \mathrm{mgO}_{2} / \mathrm{g} \mathrm{TOC}\right.$ ) represents the amount of oxygen that is associated with organic carbon and released as $\mathrm{CO}$ and $\mathrm{CO}_{2}$ during the pyrolysis of the organic matter, which is then normalized to the Total Organic Carbon (TOC). The Hydrogen Index (HI, mg HC/g TOC) represents the amount of hydrocarbonaceous compounds that are released during pyrolysis, which is then normalized to the TOC.

\subsubsection{Mineral geochemistry}

A portative ED-XRF spectrometer (S1 TITAN Bruker) was used to measure the major elements, which were expressed as a relative percentage of oxides. Analysis of both gently crushed soil and sediment samples was performed through a 4- $\mu \mathrm{m}$-thick Ultralene film in a 32mm-diameter plastic cup. The samples were triplicated and analyzed over $60 \mathrm{~s}$ by using the GeoChem Standard instrument's internal calibration mode (Shand and Wendler, 2014). The organic matter content that was deduced from the $\mathrm{LOI}$ at $550{ }^{\circ} \mathrm{C}$ was added to the sum of the major elements $\left(\mathrm{Al}_{2} \mathrm{O}_{3}, \mathrm{SiO}_{2}, \mathrm{~K}_{2} \mathrm{O}, \mathrm{CaO}, \mathrm{TiO}_{2}\right.$ and $\left.\mathrm{Fe}_{2} \mathrm{O}_{3}\right)$. Consequently, the elemental results were brought to $100 \%$ to overcome the closedsum effects that are linked to OM variations (Baize, 2000). The standard deviations of the replicates were lower than the errors by the instrument, which were thus conserved as measurement uncertainties.

\subsection{Estimating the erosion and soil formation}

\subsubsection{Sediment dry density (DD)}

The density of the sediment was calculated every 0.5 or $2 \mathrm{~cm}$ from the dry weight of a known volume of sediment. The 651 sampled volumes were 8.2 or $15.9 \mathrm{~cm}^{3}$ according to the sampling.

\subsubsection{Estimating the deposit}

The volume of sediment in the lake was modeled as a semi-ellipsoid that was fitted to the dimensions of the lake: the oval surface of the lake is approximately $465 \times 156 \mathrm{~m}$. The lake contains $8 \mathrm{~m}$ of water and $18 \mathrm{~m}$ of sediment. The volume ( $\mathrm{V}$ ) of each layer of sediment was estimated by subtracting half-ellipsoids for each depth based on the first $6.2 \mathrm{~m}$ of the sediment core (see Supplemental material S1 for details).

The mass of sediment $\left(\mathrm{M}_{\mathrm{sed}}\right)$ at each depth was calculated as

$\mathrm{M}_{\text {sed }}[\mathrm{t}]=\mathrm{DD}\left[\mathrm{g} / \mathrm{cm}^{3} \times \mathrm{V} \mathrm{m} \mathrm{m}^{3}\right]$

\subsubsection{Estimating erosion}

Only the terrigenous component of the sediment (TS) was considered using the final LOI residue (i.e., Non-Carbonate Ignition Residue after the $950{ }^{\circ} \mathrm{C}$ ignition phase) to estimate the erosion (E) or sediment yield (SY). The TS was integrated according to the time (T) that was covered by the layer of sediment as deduced from the age-depth model. Following this approach, the $\mathrm{OM}$ and carbonate fractions were neglected in the sediment budget because these factors could be produced and precipitated within the lake.

$\mathrm{TS}[\mathrm{t} / \mathrm{yr}]=\mathrm{M}_{\mathrm{sed}}[\mathrm{t}] \times \% \mathrm{NCIR} / \mathrm{T}[\mathrm{yr}]$
Then, the TS was divided by the potential surface of erosion (S), which initially corresponds to the surface of the catchment:

$\mathrm{SY}=\mathrm{E}\left[\mathrm{t} / \mathrm{km}^{2} / \mathrm{yr}=\mathrm{TS} \mathrm{t} / \mathrm{yr} / \mathrm{S} \mathrm{km}^{2}\right]$

Finally, the erosion equation could be written as.

$\mathrm{E}=\frac{\mathrm{DD} \times \mathrm{V} \times \mathrm{NCIR}}{\mathrm{T} \times \mathrm{S}}$

\subsubsection{Soil bulk density (BD)}

A mean soil density value was required to reconstruct the evolution of the soil thickness with time in the catchment from the weighted sediment filling of the lake. We chose to use a single average value because this value varies through time, e.g., with vegetation and practices. We could use the bulk density of the current soil, but the presence of numerous coarse elements makes sampling known volumes of soil with a cylinder difficult (Nasri et al., 2015), especially in mountain areas. Additionally, we could estimate this density from the physicochemical parameters of the soil. Numerous pedotransfer functions (PTF) exist in the literature that consider several such parameters. According to Dupouey et al. (1997), the organic carbon (Corg) and the depth of the soil horizon are the two most important parameters in the prediction of the bulk density (BD) of the 2-mm sifted fraction. We chose the mean BD value, which was calculated with empirical relationships that were developed by Harrison and Bocock (1981) and Zinke et al. (1986). Their relationships, which were established from various soils in Europe, only consider the depth and the organic matter and carbon contents of the soil.

\subsubsection{Denudation rate or soil loss}

The erosion was converted into the loss soil thickness (SL) with the dry bulk density (BD) of the 2-mm sifted fraction of the current soils. This factor represents only the fine earth fraction, so this thickness was increased by $50 \%$ by considering a skeleton with $50 \%$ for coarse elements and plant macroremains (Egli et al., 2001, 2014).

$\mathrm{SL}[\mathrm{mm} / \mathrm{yr}]=\mathrm{E}\left[\mathrm{t} / \mathrm{km}^{2} / \mathrm{yr} / \mathrm{BD} \mathrm{g} / \mathrm{cm}^{3}\right] / 1000 \times 2$

\subsubsection{Estimating soil formation}

The soil formation rate was estimated to assess the tolerable soil loss with respect to erosion by using data synthesis and the equation of the soil formation rate $\mathrm{SF}=\left[\mathrm{t} / \mathrm{km}^{2} / \mathrm{yr}\right]$ vs the surface age $[\mathrm{y}=$ $5110,9 x^{-0,505}$ ], which was given by Egli et al. (2014) for European Alps. This equation was developed with silicated parent material soils. Such an equation does not exist for carbonated substrates. However, we could develop a suitable with carbonate mass flux data (see Supplemental material S2). However, this equation does not involve much data, so its confidence is low and the equation for silicated parent material was preferred despite the carbonated geological context of the Lake La Thuile catchment.

This equation was transcribed in $\mathrm{cm} / \mathrm{yr}$ with the $\mathrm{BD}$ of the soil $(\mathrm{BD}=1,15)$ and integrated in time $(\mathrm{t})$ to obtain the relationship between the soil thickness ST $=[\mathrm{cm}]$ and surface age:

$$
\begin{aligned}
& \mathrm{SF}[\mathrm{cm} / \mathrm{yr}]=0,444 \mathrm{t}^{-0,505} \quad \mathrm{t}=[\mathrm{yr}] \\
& \mathrm{ST}[\mathrm{cm}]=\int_{\mathrm{t} 1}^{\mathrm{t} 2} \mathrm{SF}=0,444 /(1-0,505) \cdot \mathrm{t}^{(1-0,505)} \quad \mathrm{t}=[\mathrm{yr}]
\end{aligned}
$$

Then, we could establish the relationship between the soil formation rate and the thickness:

$\mathrm{SF}[\mathrm{cm} / \mathrm{yr}]=0,4 \mathrm{ST}^{-1,02} \quad \mathrm{ST}=[\mathrm{cm}]$ 
Considering an initial $\left(\mathrm{t}_{1}\right)$ soil thickness $\mathrm{ST}_{1}$ enabled us to calculate the thickness of the soil that formed between $t_{1}$ and $t_{2}$ and the resulting thickness $\left(\mathrm{ST}_{2}\right)$ at $\mathrm{t}_{2}$, including the erosion $\mathrm{E}[\mathrm{cm} / \mathrm{yr}]$ between $\mathrm{t}_{1}$ and $\mathrm{t}_{2}$ :

$\mathrm{ST}_{2}[\mathrm{~cm}]=\mathrm{ST}_{1}+0,4 \cdot \mathrm{ST}_{1}^{-1,02 \cdot}\left(t_{2}-\mathrm{t}_{1}\right)-\mathrm{E} \cdot\left(\mathrm{t}_{2}-\mathrm{t}_{1}\right)$

The glacial retreat in the Lake La Thuile catchment was estimated to be between 16 and $20 \mathrm{kyr}$ BP, which matches our age-depth model for the late-glacial portion of the sediment sequence (unpublished data). Thus, the soils may have developed after this date. Considering this uncertainty, we assumed an initial soil thickness at 12,000 cal. BP between 1 and $50 \mathrm{~cm}$ to model its evolution.

Considering the evolution of the soil thickness, the soil formation rate was calculated at each time as:

$\mathrm{SF}_{(\mathrm{t})}[\mathrm{cm} / \mathrm{yr}]=0,4 \mathrm{ST}_{(\mathrm{t}-1)}{ }^{-1,02} \quad \mathrm{ST}=[\mathrm{cm}]$

Finally, the soil balance was deduced by the difference between the soil formation and soil loss to access the tolerable erosion (when SF $\geq$ SL).

\section{Results and discussion}

\subsection{Soils of the catchment}

Three main soil types have been distinguished in the catchment according to their main evolutionary process (e.g., humification, decarbonatation and acidification), $\mathrm{pH}$ and parent material.

\subsubsection{Cambisols (Eutric and Dystric)}

The soils in the northern and upper area of the catchment that are developed under planted pine forest are Dystric (THU01) to Eutric (THU02) Cambisols (Fig. 3). THU01 is a clay-loam soil with a blocky structure. This soil is acidic with pH from 4.5 to 5.5 (Fig. 3). THU01 exhibits abundant charcoals at depths from approximately 20 to $70 \mathrm{~cm}$. Rust patterns are also visible in the deepest horizons. THU02 developed on carbonated rocks, but its upper horizons are decarbonated. The $\mathrm{pH}$ is acidic to neutral, except in the $\mathrm{C}$ horizons where the matrix is carbonated (effervescent with an acid solution: $\mathrm{Cca}$ ). The structure is blocky and the texture is silt loam. The LOI at $950{ }^{\circ} \mathrm{C}$ for THU01 and THU02 are negligible $(<2 \%)$, except in the Cca horizon of THU02, where this value reaches $10 \%$ (Fig. 3 ).

\subsubsection{Cambisols (Calcaric)}

The soils THU03, THU05 and THU07 (Fig. 3) in the lower area of the catchment are Calcaric Cambisols. These soils are developed under grazed pastures around the lake and are defined by their effervescence to hydrochloric acid within all horizons and their high $\mathrm{pH}(\sim 8)$. The LOI at $950{ }^{\circ} \mathrm{C}$ is close to $20 \%$ on average. THU03 exhibits coarse elements throughout the profile, a good structure and a silty loam texture. THU05 developed on a stabilized alluvial fan.

THU04 is a particular case of Calcaric Cambisols because of the presence of a colluvic horizon between 25 and $40 \mathrm{~cm}$ (Bwca), which consists of numerous angular carbonated rock elements (Fig. 3). This horizon covers an old soil, likely a Eutric Cambisol, because of the absence of reaction to hypochloric acid (Bw) and the low LOI value at $950{ }^{\circ} \mathrm{C}$. Colluvium allowed the development of a carbonated horizon at the surface (Aca). The pH of the soil is approximately 8, as with the other Calcaric Cambisols.

The thickness of both Cambisols varied from 60 to $80 \mathrm{~cm}$ (Fig. 3). The LOI at $550{ }^{\circ} \mathrm{C}$ decreased with depth and was equivalent between soils and horizon, except for the $\mathrm{O}$ horizon of THU02.

\subsubsection{Folic Umbrisols}

The THU06 soils that developed on Tithonic formations are very thin (Fig. 3) and developed under forests. These soils mainly consist of an accumulation of organic matter (30 to 40\%) and are buffered: all the parameters, i.e., LOI, Oxygen Index and $\mathrm{pH}$ (close to 7 ), are constant throughout the profile (Fig. 3). The parent material, which mainly consists of $\mathrm{CaCO}_{3}$ (95\%), does not contain enough clay or silt to develop proper horizons (Duchaufour, 1970; Legros, 2007). Considering these soils' nature, the productivity of Folic Umbrisols is very limited for agricultural purposes.

\subsection{Origin of the organic matter}

The organic geochemistry results of the soil samples are presented in Fig. 3 and in the pseudo-van Krevelen diagram with sediment samples (Fig. 4). For all the Cambisols, the OI increases with depth and ranges from approximately 200 (A horizons) at the surface to $2000 \mathrm{mg} \mathrm{O}_{2} / \mathrm{g}$ in the deepest $\mathrm{B}$ and $\mathrm{C}$ horizons (Figs. 3 and 4). The $\mathrm{HI}$ ranges from approximately 100 to $500 \mathrm{mg} \mathrm{HC} / \mathrm{g}$ and slightly decreases with depth in THU01, THU02, THU04, and THU05. These OI and HI variations are consistent with the expected OM freshness and humification process in soils with depth (Di-Giovanni et al., 2000; Disnar et al., 2003; Saenger et al., 2013, 2015). Three soil samples (Bwg in THU04, Cca in THU03 and Sca2 between 40 and $60 \mathrm{~cm}$ in THU07) have both high OI and HI: $\mathrm{OI}>1000 \mathrm{mg} \mathrm{O}_{2} / \mathrm{g}$ and $\mathrm{HI}>300 \mathrm{mg} \mathrm{HC} / \mathrm{g}$ (Figs. 3 and 4) and display the lowest OM contents (Fig. 3). The OI and HI were normalized to the TOC, so the OI and HI values for these samples are irrelevant. The horizons of the Folic Umbrisols have $\mathrm{HI}$ and OI values on the order of Cambisols surface horizons ( $300 \mathrm{mg} \mathrm{HC} / \mathrm{g}$ and $270 \mathrm{mg} \mathrm{O} / \mathrm{g}$, respectively), which matches with the humus nature of this soil.

In the pseudo-van Krevelen diagram (Fig. 4), the sediments between 12 and 1,6 kyr cal. BP have high HI and low OI, which suggest a lacustrine origin of the OM in the sediment (Disnar et al., 2003). With time, the $\mathrm{HI}$ of the sediment decreased and the OI increased reaching the same values as those of the soils samples after $1600 \mathrm{cal}$. BP, which suggest these soils as the source of OM. Only the most recent sediment samples ( 700 to -50 cal. BP) did not follow this trend and had higher $\mathrm{HI}$ values and lower OI values than samples from the previous period (1400 to $1000 \mathrm{cal}$. BP). This evolution of both the HI and OI in the sediment through the Holocene suggests a change in the origin of the OM. We could interpret similar patterns in the OI and HI values of these sediments as reflecting contributions from surface (A horizons) or deep (B then $C$ ) soil horizons (Figs. 4, 5). The gradual increasing OI in the sediment between 1600 and $1000 \mathrm{yr}$ cal. BP (Fig. 5) indicates an evolution of OM inputs that could be explained by the erosion of increasingly deep soil.

\subsection{Weathering processes}

Both the $\mathrm{K}$ and $\mathrm{Al}$ in the soils were normalized with respect to Ti to study their dynamics (Fig. 6a). Ti is commonly considered to be immobile in soils because this element is poorly weathered throughout pedogenesis (Egli et al., 2001; Brantley and Lebedeva, 2011). Because we discussed the mineral geochemistry, $O$ horizons with $50 \%$ or greater OM content were not plotted in Fig. 6a.

The $\mathrm{K}_{2} \mathrm{O} / \mathrm{TiO}_{2}$ ratios from the soil samples ranged from 1.5 to 2.8 and enabled us to distinguish soils into two classes: the first had ratios between 1.5 and 2 and the second had ratios between 2 and 2.8. In the first class, THU01, THU02 and THU06 also had the lowest pH (Fig. 3), except for the Cca horizons. These soils developed under forests and had the most advanced pedogenesis. In the second class, THU03, THU04, THU05 and THU07 were all Calcaric Cambisols with high pH that developed under grasslands. The $\mathrm{K}_{2} \mathrm{O} / \mathrm{TiO}_{2}$ ratios increased with depth for most of the soils.

The soils in the catchment had $\mathrm{Al}_{2} \mathrm{O}_{3} / \mathrm{TiO}_{2}$ ratios that ranged from 10 to 20. The $\mathrm{Al}_{2} \mathrm{O}_{3} / \mathrm{TiO}_{2}$ ratios increased with depth in THU01, THU02 and THU04 but were constant with depth in THU03, THU05 and THU07 (Fig. 6a). The Folic Umbrisol (THU06) exhibited both low $\mathrm{Al}_{2} \mathrm{O}_{3} / \mathrm{TiO}_{2}$ and $\mathrm{K}_{2} \mathrm{O} / \mathrm{TiO}_{2}$ ratios. 


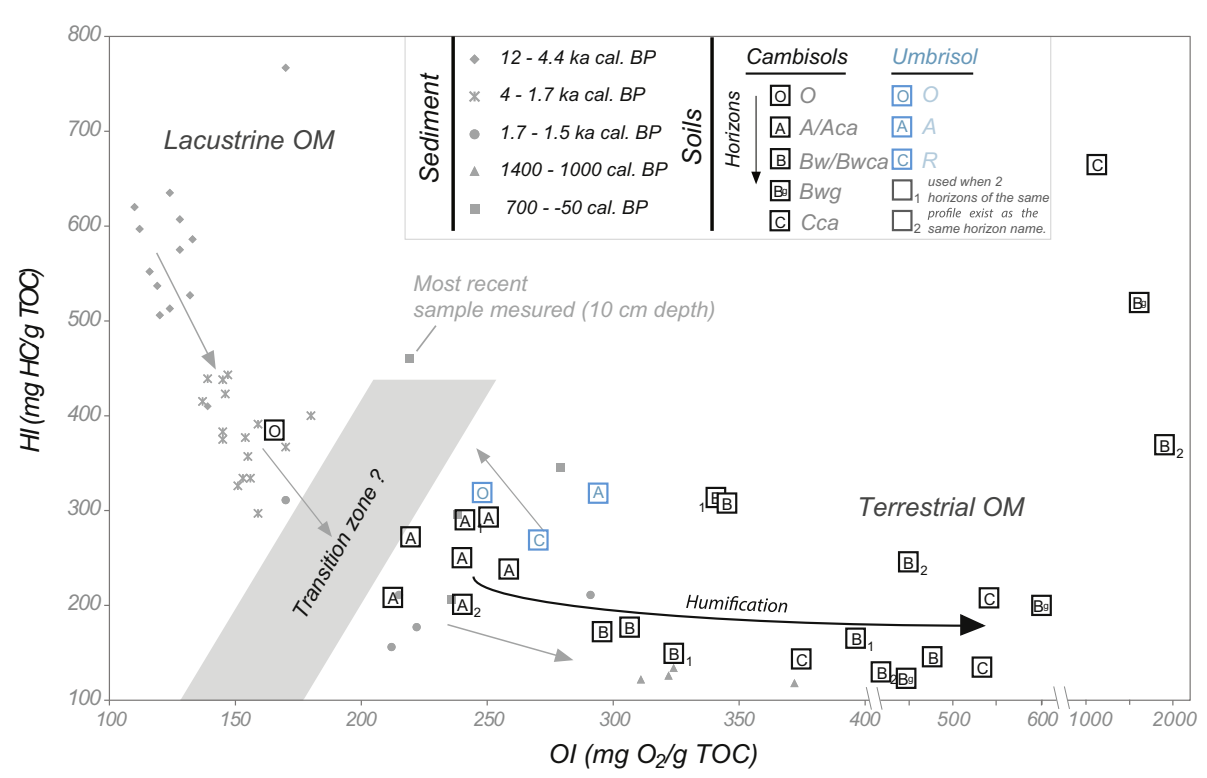

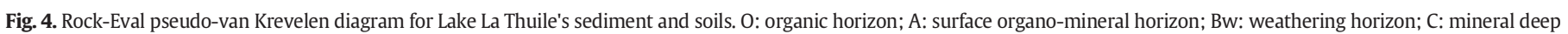
horizon; - ca: effervescence to $\mathrm{HCl}$ in the horizon; -g: gleyic character of the horizon.

The $\mathrm{K}_{2} \mathrm{O} / \mathrm{TiO}_{2}$ and $\mathrm{Al}_{2} \mathrm{O}_{3} / \mathrm{TiO}_{2}$ ratios for the sediment samples were plotted over the soil sample ratios, which are represented as rectangular expanses in Fig. 6b. The ratios from the soil and sediment samples were similar and overlapped, excluding an enrichment or depletion when transferred to the lake. The sediment samples seemed to be grouped by time spans. Sediments with ages between 4000 and $1550 \mathrm{yr}$ cal. BP had ratios that ranged from 10 to 15 and from 2 to 2.6, respectively. Sediments between 1550 and $1150 \mathrm{yr}$ cal. $\mathrm{BP}$ had the lowest $\mathrm{Al}_{2} \mathrm{O}_{3} / \mathrm{TiO}_{2}$ ratios (from 9 to 15 ) and $\mathrm{K}_{2} \mathrm{O} / \mathrm{TiO}_{2}$ ratios (from 1.4 to 2.2). Sediments with ages from 1150 to 850 and from 200 to $0 \mathrm{yr}$ cal. BP had high $\mathrm{K}_{2} \mathrm{O} / \mathrm{TiO}_{2}$ and $\mathrm{Al}_{2} \mathrm{O}_{3} / \mathrm{TiO}_{2}$ ratios. Sediments between 850 and $400 \mathrm{yr}$ cal. BP and the most recent sediments (1950-2010 cal. AD) also had high $\mathrm{K}_{2} \mathrm{O} / \mathrm{TiO}_{2}$ ratios but lower $\mathrm{Al}_{2} \mathrm{O}_{3} / \mathrm{TiO}_{2}$ ratios.

The $\mathrm{Al}_{2} \mathrm{O}_{3} / \mathrm{TiO}_{2}$ and $\mathrm{K}_{2} \mathrm{O} / \mathrm{TiO}_{2}$ ratios that were measured with the P-XRF on dried sediment samples were compared to the $\mathrm{Al} / \mathrm{Ti}$ and $\mathrm{K} / \mathrm{Ti}$ ratios that were measured with a core scanner on undisturbed core sections (Bajard et al., 2016). The variations that were recorded by both XRF analysis methods were coherent (Fig. 5).

\subsubsection{Potassium mobility}

A comparison of the mineral geochemistry of the soils and sediment enabled us to associate sediment to preferential soil sources. $\mathrm{K}$ is easily lixiviated when rocks weather (Egli et al., 2001; Arnaud et al., 2012). Deep horizons, which are close to the parent material, are richer in $\mathrm{K}$, whereas well-weathered horizons that are close to the surface are depleted in K (Fig. 6a). Dystric and Eutric Cambisols are more developed and weathered than Calcaric soils and are thus more depleted in $\mathrm{K}$; acidification assists this process. The $\mathrm{K}_{2} \mathrm{O} / \mathrm{TiO}_{2}$ ratio can thus be used as an indicator of weathering (Arnaud et al., 2012) to distinguish in the sediment when erosion comes from Calcaric or Eutric to Dystric Cambisols and to determine whether eroded material comes from deep or surface horizons (Fig. 7). In $\mathrm{THU} 04$, the $\mathrm{K}_{2} \mathrm{O} / \mathrm{TiO}_{2}$ ratio remained relatively constant because of the transfer of potassium in its deeper area (Fig. 6a), possibly because of the contribution of colluvium.

\subsubsection{Aluminum mobility}

The solubility of aluminum in soil depends on the $\mathrm{pH}$. Al depletion is favored by pH below 5 (Chamayou and Legros, 1989) and is faster in topsoil (Egli et al., 2001). As long as soils have high pH (THU03, THU05, THU07), aluminum is immobile, as shown with the constant
$\mathrm{Al}_{2} \mathrm{O}_{3} / \mathrm{TiO}_{2}$ ratios for Calcaric Cambisols (Fig. 6a). Soils with low pH (Eutric to Dystric Cambisols: THU01 and THU02) exhibits increasing $\mathrm{Al}_{2} \mathrm{O}_{3} / \mathrm{TiO}_{2}$ ratios with depth. Thus, the $\mathrm{Al}_{2} \mathrm{O}_{3} / \mathrm{TiO}_{2}$ ratio can be used to distinguish soil horizons with low $\mathrm{pH}$. We can compare the mineral geochemistry of soils and sediments, so the $\mathrm{Al}_{2} \mathrm{O}_{3} / \mathrm{TiO}_{2}$ ratios can be used as a secondary indicator of the eroded soil depth, especially for Eutric to Dystric Cambisols (Figs. 5, 7). This ratio's variations seem consistent with the interpretation of $\mathrm{OI}$ and $\mathrm{K}_{2} \mathrm{O} / \mathrm{TiO}_{2}$ with depth and complement each other. THUO4 exhibits two different $\mathrm{Al}_{2} \mathrm{O}_{3} / \mathrm{TiO}_{2}$ ratios because of its composite nature (Fig. 3). The rejuvenation of these soils by colluvic calcium carbonate inputs seemed to stabilize the $\mathrm{pH}$ and the aluminum mobility in the deepest old horizons.

\subsection{Erosion of the catchment and soil evolution}

Considering the low development of soils over the Tithonic formations (Folic Umbrisols), the erosion was calculated at the catchment scale by removing the soil's surface. The potential erosion surface was thus reduced to $1.2 \mathrm{~km}^{2}$.

\subsubsection{Erosion}

From 12,000 to $2500 \mathrm{yr}$ cal. BP, erosion remained relatively stable and ranged between 0.1 and $1 \mathrm{t} \cdot \mathrm{km}^{-2} \cdot \mathrm{yr}^{-1}$ (Fig. 8a). A succession of increases was recorded, first between 2500 and 1600 cal. BP with erosion reaching $7 \mathrm{t} \cdot \mathrm{km}^{-2} \cdot \mathrm{yr}^{-1}$, and then between 1600 and 1200 yr cal. BP (105 t $\left.\cdot \mathrm{km}^{-2} \cdot \mathrm{yr}^{-1}\right)$ and between 1200 and $800 \mathrm{cal}$. BP (Figs. $8 \mathrm{a}$ and 5). Erosion reached its highest values between 1000 and 800 yr cal. BP (approximately $450 \mathrm{t} \cdot \mathrm{km}^{-2} \cdot \mathrm{yr}^{-1}$ on average). All these values are comparable to the current erosion rate, e.g., the value that was modeled for Europe (Cerdan et al., 2010) or calculated for mountain areas (Egli et al., 2014), for catchments of similar size as La Thuile (Verstraeten and Poesen, 2002; Vanmaercke et al., 2015). These values are also close to past erosion rates that were recorded with similar methods in lake sediments (Enters et al., 2008; Foucher et al., 2015).

\subsubsection{Soil loss}

The mean soil densities that were estimated with different depth combinations (for all horizons, or for only the first 30 or $40 \mathrm{~cm}$, with or without Folic Umbrisol) produced values from approximately 1 to 1.30. We consider a BD of 1.15 in the following sections, and the sensitivity of this parameter was calculated with BDs of 0.8 and 1.50 . 


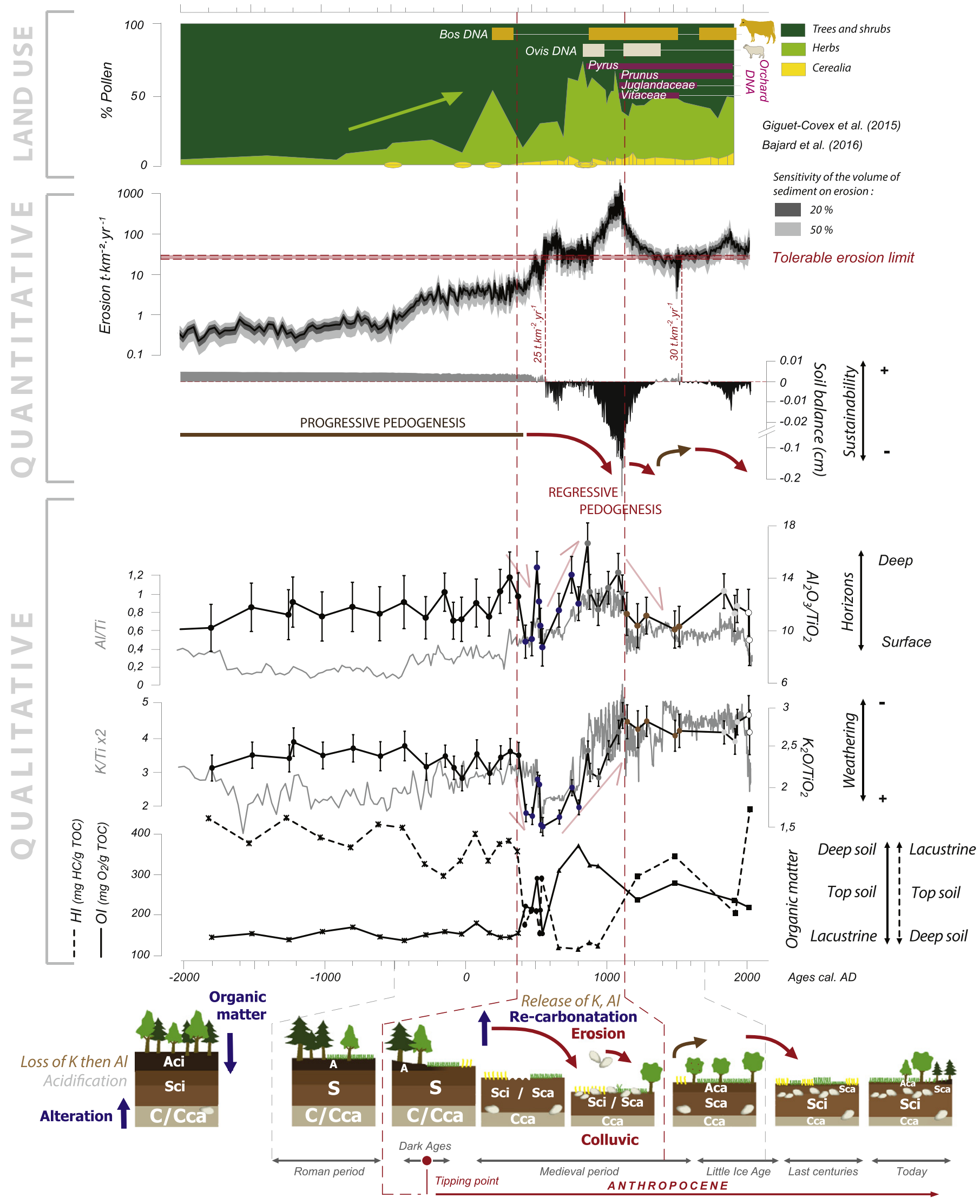

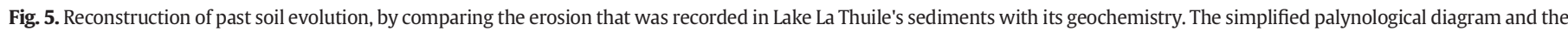

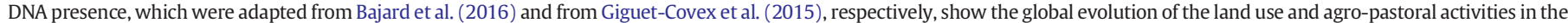

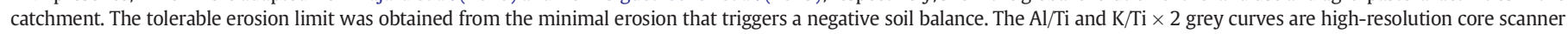

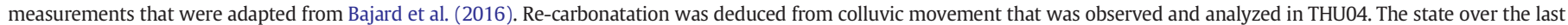
centuries state was deduced from the landscape in Fig. 2. 
The lost soil thickness was deduced from erosion by considering a BD of 1.15 (Fig. 8a) and a skeleton of 50\%. Throughout the last 4000 years cal. BP, the soil loss ranged from 0 to $2.6 \mathrm{~mm} \cdot \mathrm{yr}^{-1}$, with an average of approximately $0.17 \pm 0.01 \mathrm{~mm} \cdot \mathrm{yr}^{-1}$. The resulting loss of soil throughout the Holocene represents approximately $22 \pm 3 \mathrm{~cm}$ of soil, of which 3/4 was lost during the last 1000 years.

\subsubsection{Sensitivity analysis}

A sensitivity analysis was performed to verify the robustness of the model and determine the influence of changes in the parameters from the erosion equation (i.e., the volume $\mathrm{V}$, the density $\mathrm{DD}$, the content in NCIR of the sediment and the deposition time T of the volume), which changed one parameter at a time with the sensitivity coefficient $Q_{(i, p)}$. This equation is typically expressed as the partial derivative of the erosion E with respect to each of the parameters $p$ (Furrer et al., 1989; Egli and Fitze, 2001; ten Broeke et al., 2016) and can be calculated at each depth i:

$\mathrm{Q}_{(i, p)}=\frac{\partial E i}{\partial P} \times \frac{P i}{E i}$

A change of $1 \%$ in the parameter $p$ at a depth $i$ will trigger a $\mathrm{Q} \%$ change in erosion at the depth $i$. The same methodology was applied for the soil loss with the erosion and soil bulk density parameters.

Both equations are linear and of the first degree, so the $Q_{(i, p)}$ solutions are 1 or -1 (Table 1 ), depending on whether the parameter increases $(Q=1)$ or decrease $(Q=-1)$ the erosion.

For example, a $10 \%$ increase in the sediment volume increases erosion by $10 \%$. A $15 \%$ increase in the BD decreases the soil loss by $15 \%$.

Among the parameters in Table 1, the volume of sediment and the BD were not measured with the sediment core. Thus, only their uncertainties are represented in Fig. 8, with the volume increasing and decreasing by 20 and $50 \%$ and the densities varying from 0.80 to 1.50 . Neither the volume of sediment nor the soil bulk density was sensitive to large time-scale variations in the erosion or soil loss, respectively.

\subsubsection{Soil formation}

Considering the silicated parent material soil evolution model, the soil thickness grew fast at the beginning of the pedogenesis, with approximately 40 and $20 \mathrm{~cm}$ over 2000 years between 12 and $10 \mathrm{ky} \mathrm{cal}$. $\mathrm{BP}$ and with initial soil depths of 1 and $50 \mathrm{~cm}$, respectively (Fig. 8b). Conversely, the soil formation rates decreased quickly at the beginning of the pedogenesis (Fig. 8c). The deepening slowed down with increasing thickness, and the difference between the two curves was reduced (Fig. 8b, c). The soil thickness abruptly lost dozens of $\mathrm{cm}$ between approximately 1000 and $800 \mathrm{yr}$ cal. BP because of erosion. At this time, the soil formation rate slightly increased in response to this loss of thickness. The current thickness ranges from $75 \mathrm{~cm}$ to $85 \mathrm{~cm}$ for initial Holocene depths of 1 and $50 \mathrm{~cm}$, respectively, which is quite reasonable in terms of the 70-cm depth of the current soils (Fig. 3). The soil balance showed positive values between 4000 and $1400 \mathrm{yr}$ cal. BP and between 650 and $400 \mathrm{yr}$ cal. BP and negative values between 1400 and $650 \mathrm{yr}$ cal. $\mathrm{BP}$ and over the last $400 \mathrm{yr}$ cal. BP (Fig. 5). The amount of tolerable erosion can be determined when erosion is compensated by soil formation and corresponds to the minimal erosion that is triggered when the soil balance is negative. Soil formation depends on the soil thickness, so tolerable erosion also depends on the soil thickness. The tolerable erosion ranged from 25 to $30 \mathrm{t} \cdot \mathrm{km}^{-2} \cdot \mathrm{yr}^{-1}\left(0.004\right.$ to $\left.0.005 \mathrm{~cm} \cdot \mathrm{yr}^{-1}\right)$ for periods between 1400 and $650 \mathrm{yr}$ cal. BP and from $400 \mathrm{yr}$ cal. BP to the present, respectively (Fig. 5).

The carbonated parent material soil evolution model (see Supplemental material S2) depends more on the initial thickness than the silicated model (Fig. 8b). This parameter involves much more important soil thicknesses. Consequently, the modeled current thicknesses are too important compared to the current soil thicknesses and confirm the poorer assessment of this model.

\subsubsection{From soils to sediment}

The particle-size of the sediment was relatively constant between approximately 1600 and $-50 \mathrm{yr}$ cal. BP ( $\max$ SD was 1,05\%), precluding particle-size-dependent changes in the mineral geochemistry (Bajard et al., 2016). Otherwise, the local variability in the rock sources cannot be excluded to explain differences in the soil or sediment geochemistry.

Deposits that were derived from eroded soils upstream from the lake, e.g., as colluvium or an alluvial fan (THU04 and THU05, respectively), could have caused the erosion that was quantified from the lake sediment to be underestimated. Conversely, a portion of the eroded material could have been cleared out at the outlet of the lake. If this second process could be neglected, the first process includes the variability in the erosion of the catchment, e.g., terraces that could have been implemented to limit erosion. Furthermore, the quantification of erosion with volume increases and decreases by 20 and 50\% did not vary much (Fig. 8), which indicates that the accuracy of the sediment filling volume of the lake was not essential in the quantification. This quantification greatly depended on the age depth model of the sediment sequence, but according to Edwards and Whittington (2001), this sedimentation pattern reflected the gross sensitivity of landscape catchments to natural and anthropogenic pressures. The estimation of the eroded soil thickness also did not greatly depend on the chosen density on our scale (Fig. 8a). The density varies, especially with practices, so afforestation and culturing would have increased this value and decreased the corresponding soil thickness. Over the last 4000 years, the different thicknesses between soils with initial depths of 1 and $50 \mathrm{~cm}$ did not exceed a dozen centimeters. Thus, the initial soil depth at the beginning of the Holocene did not seem to be essential to estimate the soil thickness during the Early Holocene period. Defining a soil depth of $50 \mathrm{~cm}$ at 12,000 years ago would correspond to setting the beginning of pedogenesis at approximately $16 \mathrm{kyr}$ cal. BP (Fig. 8). This condition is more reasonable that a boreal forest covered the catchment 12,000 years ago (Bajard et al., 2016). The evolution of the vegetation during the early and mid-Holocene and the low erosion suggest the progressive development of soils, which was supported by the soil formation model (Fig. 8). The soil evolution would have been controlled by decarbonatation and then by acidification, as attested by the development of resinous trees, such as fir, 8000 years ago (Bajard et al., 2016). Similar soil development patterns have also been reconstructed through geochemical analyses of sediment from Lake Anterne (Giguet-Covex et al., 2011).

\subsection{Evolution of soils over the past 4000 years in La Thuile watershed}

1 - From 4000 to $2500 \mathrm{yr}$ cal. BP, erosion was low, approximately between 0.2 and $1.5 \mathrm{t} \cdot \mathrm{km}^{-2} \cdot \mathrm{yr}^{-1}$ (Fig. 5), and corresponded to values that are observed under stable forest ecosystems. The OI was close to $150 \mathrm{mg} \mathrm{O} / \mathrm{g}$ on average, and the $\mathrm{HI}$ was around $400 \mathrm{mg} \mathrm{HC} / \mathrm{g}$ (Fig. 5), which characterize organic matter with a lacustrine origin. The $\mathrm{K}_{2} \mathrm{O} / \mathrm{TiO}_{2}$ and $\mathrm{Al}_{2} \mathrm{O}_{3} / \mathrm{TiO}_{2}$ ratios were also constant, ranging from 2 to 2.5 and close to 12 , respectively (Fig. 5). During this period, the pollen results did not show any modification (Fig. 5). The landscape was forested and stable. The established soils evolved under forests. These soils were characteristic of carbonated ambiances and subjected to both decarbonatation and acidification processes, which were favored by a warm climate and the presence of resinous vegetation over several millennia (Duchaufour, 1970; Erhart, 1967). The soils were acidified, possibly reaching a pedogenetic stage that does not exist anymore in the catchment.

2 - Between 2500 and 1600 yr cal. BP, the $\mathrm{K}_{2} \mathrm{O} / \mathrm{TiO}_{2}$ and $\mathrm{Al}_{2} \mathrm{O}_{3} / \mathrm{TiO}_{2}$ ratios and $\mathrm{OI}$ did not evolve compared to the previous period, but the land use changed, with the first appearance of cerealia pollen and an increase in herbaceous pollen, suggesting the opening of the area (Bajard et al., 2016). During this period, erosion increased in response to the opening of the area but without significantly changing the soil cover 


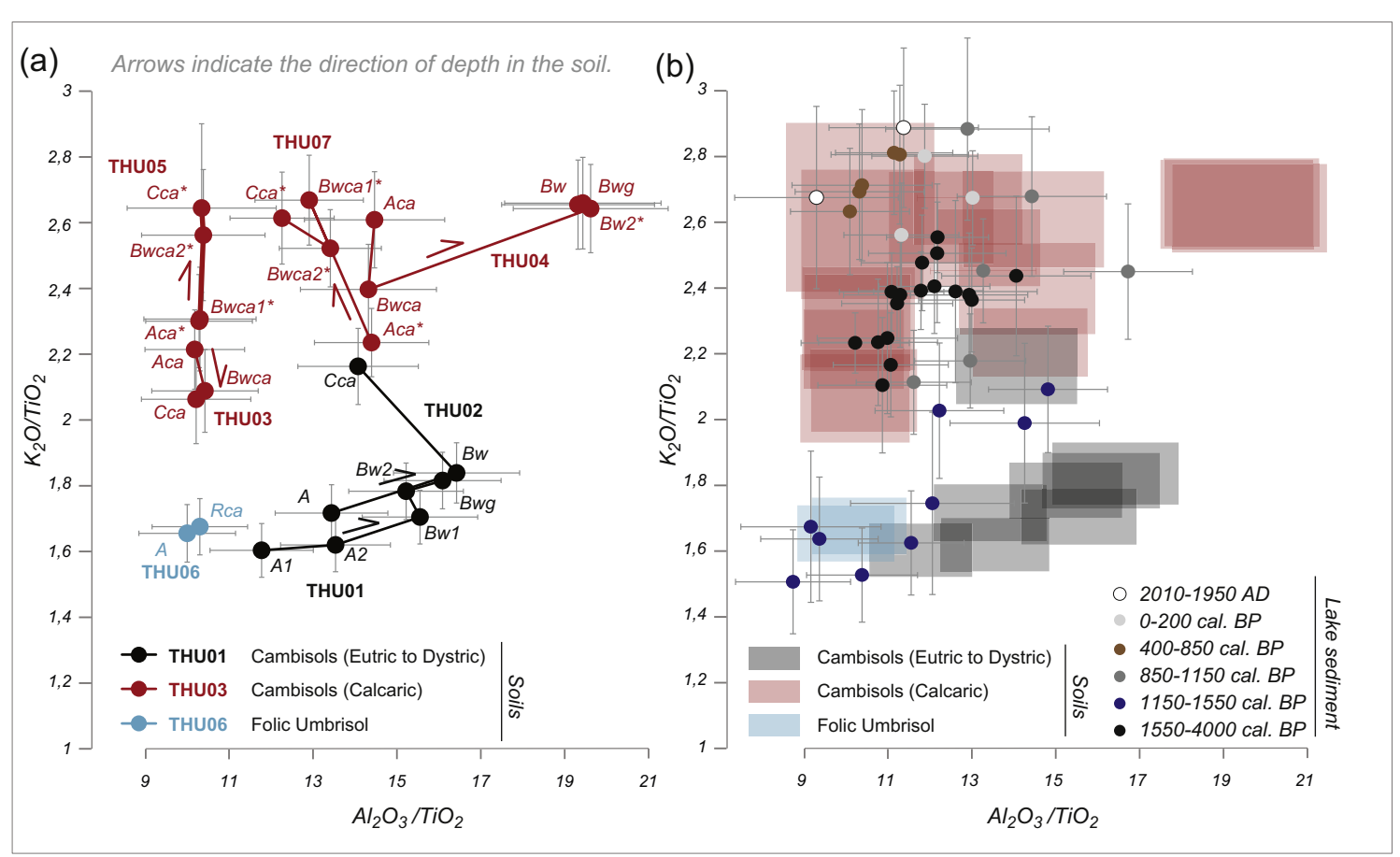

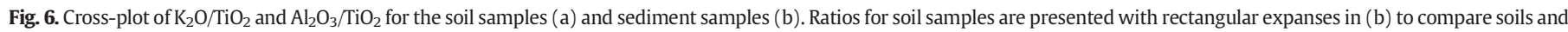
sediment. The sediment samples have been colored according to their age.

(Fig. 5). The soil balance was positive: more soil was created than eroded, reflecting a progressive pedogenesis.

3 - During 1600 to $1300 \mathrm{yr}$ cal. BP, erosion increased to approximately $100 \mathrm{t} \cdot \mathrm{km}^{-2} \cdot \mathrm{yr}^{-1}$. The OM quality changed towards higher OI values and lower Hi values, suggesting the erosion of surface soils (Fig. 5). The $\mathrm{Al}_{2} \mathrm{O}_{3} / \mathrm{TiO}_{2}$ and $\mathrm{K}_{2} \mathrm{O} / \mathrm{TiO}_{2}$ ratios decreased below 10 and 2, respectively (Fig. 6b). These geochemical features also characterized the erosion of surface soil horizons and support the previous assumption. Moreover, the very low $\mathrm{K}_{2} \mathrm{O} / \mathrm{TiO}_{2}$ ratio suggests the erosion of material with an advanced state of pedogenesis (highly weathered soils), such as Dystric Cambisols or greater. The long carbonate dissolution and acidification over the past 10,000 years could have led to even more evolved soils. The intensification of erosion could have been a response to the introduction of cereal cultures, whose pollen increased and were always present in the sediment since $1500 \mathrm{yr}$ cal. BP (Bajard et al., 2016). The tolerable erosion limit of $25 \mathrm{t} \cdot \mathrm{km}^{-2} \cdot \mathrm{yr}^{-1}$ was exceeded at approximately 1400 cal. BP. According to Cerdan et al. (2010), this erosion rate corresponds to the mean erosion that is observed under grasslands in Europe. The conversion of land use towards arable lands is possible as erosion increases. Arable lands are characterized by mean erosion rates from 160 to $1230 \mathrm{t} \cdot \mathrm{km}^{-2} \cdot \mathrm{yr}^{-1}$, which are significantly correlated to the slope gradient (Cerdan et al., 2010). The sediment's DNA did not indicate the occurrence of herds during this period (Giguet-Covex et al.,

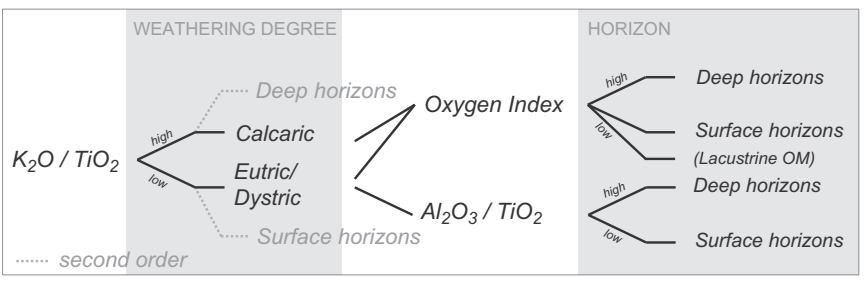

Fig. 7. Differentiation of deep and surface horizons of Calcaric or Eutric to Dystric Cambisols from the $\mathrm{K}_{2} \mathrm{O} / \mathrm{TiO}_{2}$ and $\mathrm{Al}_{2} \mathrm{O}_{3} / \mathrm{TiO}_{2}$ ratios and Oxygen Index.
2015), whereas pollen from abundant herbaceous species were recorded in the sediment since the Roman Period. Herds may have been led to the upper area of the catchment, which may have still been forested, and lands that were close to the lake may have been used for cultures. e-DNA is supposed to be preferentially adsorbed onto clay after its release from cells in the soil (Cai et al., 2006). Pastured soils may be eroded, but eroded material that potentially contains herd-DNA may not reach the lake because of their distance from the lake, whereas pollen can because they are transported by wind. This scenario supposes that herds were situated close to the lake when the e-DNA was recorded.

4 - From 1300 to $850 \mathrm{yr}$ cal. BP, the palynological results suggest the maximal expansion of deforestation. This expansion substantially affected the erosion, which reached approximately $1000 \mathrm{t} \cdot \mathrm{km}^{-2} \cdot \mathrm{yr}^{-1}$. The $\mathrm{Al}_{2} \mathrm{O}_{3} / \mathrm{TiO}_{2}$ ratio increased, which implies contributions from deep soil horizons and reflects the progressive abrasion of the soil cover. The erosion of deep horizons was also consistent with the OM signature, which exhibited high $\mathrm{OI}\left(350-400 \mathrm{mg} \mathrm{O}_{2} / \mathrm{g}\right.$ ) and low HI values (close to $100 \mathrm{mg} \mathrm{HC} / \mathrm{g}$ ). The increase in the $\mathrm{K}_{2} \mathrm{O} / \mathrm{TiO}_{2}$ ratio indicates that erosion came from less weathered soils and could be interpreted as a rejuvenation of the soils (Pallmann, 1947; Duchaufour, 1970; Egli and Poulenard, 2016). Deep and unaltered materials were remobilized and provided new carbonates to the soil profiles because of erosion. OM is known for its role in soil structuration (e.g., Chaney and Swift, 1984). Thus, erosion could have been accentuated with the loss of superficial and OMrich horizons. Erosion could also have been accentuated with the intensification of grazing. The DNA of domestic animals (Bos sp. and Ovis sp.) has been recorded in sediment younger than $1000 \mathrm{yr}$ cal. BP (GiguetCovex et al., 2015). The DNA of Ovis sp. could no longer be found since $600 \mathrm{yr}$ cal. BP, while Bos DNA was regularly detected until the present. The loss of soil reached $2 \mathrm{~mm} \cdot \mathrm{yr}^{-1}$ during this period, with $10 \mathrm{~cm}$ accumulating between 1100 and $850 \mathrm{yr}$ cal. BP, which corresponds to the Early Middle Ages. The soil balance was strongly negative. More soil was eroded than formed in the catchment. The sustainability this system was very limited, especially because the erosion was averaged over the catchment. Thus, some area of the soil cover would have 
This decrease in erosion began during the Middle Ages, a period with a growth in population (Mouthon, 2009). A lag occurred between the maximum erosion (1100 yr cal. AD/850 yr cal. BP) and population, which was also observed in Guatemala during the Maya occupation (Anselmetti et al., 2007). A decrease in erosion could reflect a change in agricultural practices. Pollen and DNA from orchard trees support the development of chestnut trees at $940 \mathrm{yr}$ cal. BP, walnuts trees at $900 \mathrm{yr}$ cal. BP, pear trees at $1100 \mathrm{yr}$ cal. BP, and trees from the Prunus genus and grapevines at $850 \mathrm{yr}$ cal. BP. Cultures of these trees are less erosive than those of cereals. Mouthon (2009) reported a division of plots between heirs during the Middle Ages with the growing population. This division of the landscape could have also limited erosion during this period by multiplying the limits that acted as barriers to erosion because hedges involved visible earthwork in the landscape.

The end of the Middle Ages and the Little Ice Age ( 700 to $300 \mathrm{yr}$ cal. $\mathrm{BP}$ ) was marked by a relative decrease in sediment yield (between 15 and $40 \mathrm{t} \cdot \mathrm{km}^{-2} \cdot \mathrm{yr}^{-1}$ ) after the Black Death, which cut the population in half (Mouthon, 2009) and induced the climatic deterioration of the Little Ice Age (Le Roy et al., 2015; Bajard et al., 2016). Erosion could be more sensitive to land use changes than precipitation changes (Paroissien et al., 2015), but a change in climate conditions could have led to a modification of the activities.

6 - Erosion increased again between $300 \mathrm{yr}$ cal. BP and the present with a maximum at approximately $80 \mathrm{cal}$. BP (1870 cal. AD), where the erosion reached $110 \mathrm{t} \cdot \mathrm{km}^{-2} \cdot \mathrm{yr}^{-1}$. This latest increase in erosion is consistent with an increase in the $\mathrm{Al}_{2} \mathrm{O}_{3} / \mathrm{TiO}_{2}$ ratio, which indicates a new incision of the soil cover and a recovery of activities after the Little Ice Age. The ratio reached the same values as those during the Medieval period (1300-850 cal. BP), while erosion was less important. These differences could have resulted from the decrease in soil thickness, which has not recovered since the Medieval period, and reflects a certain weakness of the soil cover. The soil balance was negative again and the resilience of the system did not improve. This maximum erosion was recorded approximately 30 years before old pictures of the catchment that show different cultures on the shore of the lake and pastures in the upper southern area of the catchment (Fig. 2). The OI also decreased and the HI greatly changed, which suggest the erosion of deep horizons and could reflect the effect of mixing with lacustrine OM from eutrophication of the lake, as suggested by DNA (Giguet-Covex et al., 2015), or the absence of "new" deep soil OM because of its turnover following the previous erosion crisis.

\subsection{Soil resilience in the Anthropocene}

The time between the end of the first ( $700 \mathrm{yr}$ cal. BP) and the beginning of the second ( $300 \mathrm{yr}$ cal. BP) regressive pedogenesis phases was approximately 400 years. During this time, the weathering soil signature $\left(\mathrm{K}_{2} \mathrm{O} / \mathrm{TiO}_{2}\right.$ ratio) did not recover its old characteristics (Fig. 5), which suggests that the resilience time of the soils was $>400$ years for such a disruption. The following regressive phase prevented us from estimating the full term of the resilience period because this phase interrupted the progressive phase. Nonetheless, the effects of a factor humans in this case - could persist long after its intervention (Aubert, 1960). This phenomenon could underline the polycyclic and polygenetic natures of the pedogenesis (Duchaufour, 1982), for example, with the incorporation of the colluvium material to form a complex soil (THU04) or the accumulation of charcoals between 20 and $70 \mathrm{~cm}$ in THU01. The soil evolution phase succession could also reinforce the polygenetic nature of the pedogenesis and question the real possibilities of their resilience. Associated to the substantial change in the soil cover and the negative soil balance, modifications in the soil erosion fluxes by human activities in the catchment changed the sedimentary stratigraphy of the lake since approximately $1400 \mathrm{yr}$ cal. BP. Soils are mainly controlled by the "human" factor since this period, and their current evolution trajectories are still controlled by these modifications. Thus, humans can be considered as a geologic agent since this period
Wilkinson, 2005) and a local beginning of the Anthropocene epoch can be set (Blum and Eswaran, 2004). The Anthropocene epoch (Crutzen, 2006) is not yet recognized by the International Commission on Stratigraphy (ICS) because of the global aspect of its effects, among other reasons (Finney and Edwards, 2016). Studies of local Anthropocene stratigraphy, such as in lake sediments, could assist its recognition. While several authors placed the beginning of the Anthropocene within the most recent centuries, such as the 18th or even mid-20th century (Crutzen and Steffen, 2003; Blum and Eswaran, 2004; Waters et al., 2016), the tipping point towards the Anthropocene could be defined in La Thuile's sedimentation, earlier because of the proximity of human activities and their direct effects on sedimentation. These observations could suggest an epoch that was previously identified in continental sedimentary systems and suggests substantial facies variation over the Anthropocene stratigraphy, with the diversity of each system depending on populations, activities, cultures and geology, thus defining different Anthropocene stratigraphic signatures (Blum and Eswaran, 2004). A common date for this epoch's beginning does not seem to make sense.

\section{Conclusion}

The mineral and organic geochemistry that was related to the quantification of erosion in lake sediments could be used to reconstruct the soil dynamics. Both the organic and mineral components in the studied sediment enabled us to decipher the pedogenetic origin of erosion. The Oxygen Index was comparable between soils and sediments, indicating a terrestrial origin of the organic matter in the sediment and varying with depth in the soils. The organic geochemistry represented an independent and complementary proxy from the mineral fraction to characterize the sediment inputs and their origin. The mobility of $\mathrm{K}$ and $\mathrm{Al}$ enabled us to distinguish the soil weathering states and differentiate horizons with depth. The quantification of erosion from these sediments indicated its intensity and was consistent with the geochemical dynamics. Progressive and regressive pedogenetic phases, were identified over the last 4000 years in the Lake La Thuile catchment. Between 4000 and $1400 \mathrm{yr}$ cal. BP, the soils positively developed and acidified. Then, erosion increased and the soils progressively decreased during the Middle Ages. Until 750-800 yr cal. BP, the sustainability of the system was strongly affected because the tolerable erosion limit was exceeded, causing the soil to regress. These soils were rejuvenated and durably modified with recarbonatation and colluvium movements that were triggered by erosion. During the Little Ice Age, a succession of agricultural, demographic and climatic factors decreased the erosion level, which resulted in a slight progression of the soil cover. The most recent centuries were marked by renewed regression of the soil thickness in the catchment because of change in cultural practices. Agricultural abandonment over the past 50 years changed the soil balance and initiated a positive pedogenesis phase. Humans were the most important factor that affected the major soil forming factors over the past several millennia. This triggered erosion locally changed the stratigraphy of the sediment and suggests a local boundary for the Anthropocene. We can distinguish the consequences of some management practices given the direction, magnitude, rate/duration and extent of this change (Arshad and Martin, 2002). The current challenge would be to maintain both soil ecosystem services and agro-pastoral activities in this montane catchment.

\section{Acknowledgments}

This work was conducted with the financial support of BQRIAAP Université de Savoie (2010) for coring and dating. The authors thank CLIMCORE Continent for coring facilities. 14C analyses were acquired, thanks to the CNRS-INSU ARTEMIS national radiocarbon AMS measurement program at Laboratoire de Mesure du 14C (LMC14) in the CEA Institute at Saclay (French Atomic Energy Commission). The authors 
thank also Rachel Boscardin at ISTO laboratory in Orléans for Rock-Eval analysis, and Labex VOLTAIRE (ANR-10-LABX-100-01) for financial support.

\section{Appendix A. Supplementary data}

The data reported in this paper are deposited on PANGEA: https:// doi.pangaea.de/10.1594/PANGAEA.867313. Supplementary data to this article can be found online at http://dx.doi.org/10.1016/j.catena.2016. 11.001.

\section{References}

Alewell, C., Egli, M., Meusburger, K., 2015. An attempt to estimate tolerable soil erosion rates by matching soil formation with denudation in alpine grasslands. J. Soils Sediments 15 1383-1399. http://dx.doi.org/10.1007/s11368-014-0920-6.

Anselmetti, F.S., Hodell, D.A., Ariztegui, D., Brenner, M., Rosenmeier, M.F., 2007. Quantification o soil erosion rates related to ancient Maya deforestation. Geology 35, 915-918.

Arnaud, F., Révillon, S., Debret, M., Revel, M., Chapron, E., Jacob, J., Giguet-Covex, C., Poulenard, J Magny, M., 2012. Lake Bourget regional erosion patterns reconstruction reveals Holocene NW European Alps soil evolution and paleohydrology. Quat. Sci. Rev. 51:81-92. http://dx doi.org/10.1016/j.quascirev.2012.07.025.

Arshad, M.A., Martin, S., 2002. Identifying critical limits for soil quality indicators in agroecosystems. Agric. Ecosyst. Environ. 88, 153-160.

Aubert, G., 1960. Classification et cartographie des sols: observations à la suite du 7ème congrès international de la science du sol. Congrès International de la Science du Sol, 7., s.l. (US). pp. 901-903.

Baize, D., 2000. Guide des analyses en pédologie: 2e édition, revue et augmentée. Editions Quae.

Bajard, M., Sabatier, P., David, F., Develle, A.-L., Reyss, J.-L., Fanget, B., Malet, E., Arnaud, D. Augustin, L., Crouzet, C., Poulenard, J., Arnaud, F., 2016. Erosion record in Lake La Thuile sediments (Prealps, France): evidence of montane landscape dynamics throughout the Holocene. The Holocene 26, 350-364.

Blaauw, M., 2010. Methods and code for "classical" age-modelling of radiocarbon sequences. Quat. Geochronol. 5:512-518. http://dx.doi.org/10.1016/j.quageo.2010.01.002.

Blum, W.E., Eswaran, H., 2004. Editorial: soils and sediments in the anthropocene. J. Soils Sediments 4,71

Bojko, O., Kabala, C., 2016. Transformation of physicochemical soil properties along a mountain slope due to land management and climate changes - a case study from the Karkonosz Mountains, SW Poland. Catena 140:43-54. http://dx.doi.org/10.1016/j.catena.2016.01.015.

Brantley, S.L, Lebedeva, M., 2011. Learning to read the chemistry of regolith to understand the critical zone. Annu. Rev. Earth Planet. Sci. 39:387-416. http://dx.doi.org/10.1146/annurevearth-040809-152321.

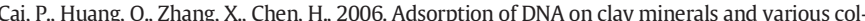
loidal particles from an Alfisol. Soil Biol. Biochem. 38:471-476. http://dx.doi.org/10.1016/j. soilbio.2005.05.019.

Cerdan, O., Govers, G., Le Bissonnais, Y., Van Oost, K., Poesen, J., Saby, N., Gobin, A., Vacca, A., Quinton, J. Auerswald, K. Klik, A. Kwaad, FJ.P.M., Raclot, D., Ionita, I., Rejman, J. Rousseva, S., Muxart, T., Roxo, M.J., Dostal, T., 2010. Rates and spatial variations of soil erosion in Europe: a study based on erosion plot data. Geomorphology 122:167-177. http://dx doi.org/10.1016/j.geomorph.2010.06.011.

Chamayou, H., Legros, J.-P., 1989. Les Bases physiques, chimiques et minéraligiques de la science du sol. Presses universitaires de France.

Chaney, K., Swift, R.S., 1984. The influence of organic matter on aggregate stability in some British soils. J. Soil Sci. 35, 223-230.

Colombaroli, D. Beckmann, M, van der Knaap, W.O. Curdy, P. Tinner, W 2013 . Changes in biodiversity and vegetation composition in the central Swiss Alps during the transition from pristine forest to first farming. Divers. Distrib. 19:157-170. http://dx.doi.org/10.1111/j. 1472-4642.2012.00930.x.

Crutzen, P.J., 2006. The "anthropocene". Springer .

Crutzen, P.J., Steffen, W., 2003. How long have we been in the Anthropocene era? Clim. Chang. 61, 251-257.

Di-Giovanni, C., Disnar, J.-R., Bakyono, J.-P., Kéravis, D., Millet, F., Olivier, J.-E., 2000. Application de l'étude de la matière organique à l'analyse de l'érosion: exemple du bassin versant $d u$ Moulin, dans les terres noires des Alpes-de-Haute-Provence (France). Comptes Rendus de l'Académie des Sciences-Series IIA-Earth and Planetary Science. 331 pp. 7-14.

Disnar, J.-R., Guillet, B., Kéravis, D., Di-Giovanni, C., Sebag, D., 2003. Soil organic matter (SOM) characterization by Rock-Eval pyrolysis: scope and limitations. Oro Geochem. 34, 327-343.

Dotterweich, M., 2013. The history of human-induced soil erosion: geomorphic legacies, early descriptions and research, and the development of soil conservation-a global synopsis. Geomorphology 201:1-34. http://dx.doi.org/10.1016/j.geomorph.2013.07.021.

Duchaufour, P., 1970. Précis de Pédologie, 3e édition. ed. Masson et Cie, Paris .

Duchaufour, P., 1982. Pedology: Pedogenesis and Classification. Allen and Unwin, London Boston

Dupouey, J.-L., Thimonier, A., Behr, P., 1997. Variations de la densité des sols des hêtraies du nord-est de la France en relation avec leurs caractéristiques physico-chimiques. Etud. Gest. Sols 4, 43-52.

Dupouey, J.-L., Dambrine, E., Laffite, J.-D., Moares, C., 2002. Irreversible impact of past land use on forest soils and biodiversity. Ecology 83, 2978-2984.

Edwards, K.J., Whittington, G., 2001. Lake sediments, erosion and landscape change during the Holocene in Britain and Ireland. Catena 42, 143-173.

Egli, Fitze, 2001. Quantitative Aspects of Carbonate Leaching of Soils With Differing Ages and Climates

Egli, M., Poulenard, J., 2016. Soils of Mountainous Landscapes. In: Richardson, D., Castree, N. Goodchild, M.F., Kobayashi, A., Liu, W., Marston, RA. (Eds.), International Encyclopedia of Geography: people, the Earth, Environment and Technology. John Wiley \& Sons, Ltd, Oxford, UK, pp. 1-10 cial deposits: results from chronosequences of Swiss alpine environments. Catena 45 , 19-47.

Egli, M. Dahms, D., Norton, K., 2014. Soil formation rates on silicate parent material in alpine environments: different approaches-different results? Geoderma 213:320-333. http://dx.doi. org/10.1016/j.geoderma.2013.08.016

Enters, D., Dorfler, W., Zolitschka, B., 2008. Historical soil erosion and land-use change during the last two millennia recorded in lake sediments of Frickenhauser See, northern Bavaria, central Germany. The Holocene 18:243-254. http://dx.doi.org/10.1177/ 0959683607086762.

Erhart, H., 1967. La génèse des sols en tant que phénomène géologique, 2ème édition, revue, corrigée et augmentée. ed, Evolution des sciences. Masson et cie, Paris

FAO, 2006. Guidelines for Soil Description, 4., [rev.] ed. ed. FAO, Rome

Finney, S.C., Edwards, L.E., 2016. The “Anthropocene" epoch: scientific decision or political statement? GSA Today 26:4-10. http://dx.doi.org/10.1130/GSATG270A.1.

Foley, J.A., 2005. Global consequences of land use. Science 309:570-574. http://dx.doi.org/10. $1126 /$ science.1111772.

Foucher, A., Salvador-Blanes, S., Evrard, O., Simonneau, A., Chapron, E., Courp, T., Cerdan, O., Lefèvre, I., Adriaensen, H., Lecompte, F., Desmet, M., 2015. Increase in soil erosion after agricultural intensification: evidence from a lowland basin in France. Anthropocene http://dx doi.org/10.1016/j.ancene.2015.02.001.

Furrer, G., Westall, J., Sollins, P., 1989. The study of soil chemistry through quasi-steady-state models: I. Mathematical definition of model. Geochim. Cosmochim. Acta 53, 595-601.

Giguet-Covex, C., Arnaud, F., Poulenard, J., Disnar, J.-R., Delhon, C., Francus, P., David, F., Enters, D., Rey, P.-J., Delannoy. J-J. 2011. Changes in erosion patterns during the Holocene in a currently treeless subalpine catchment inferred from lake sediment geochemistry (Lake Anterne, $2063 \mathrm{~m}$ a.s.l., NW French Alps): the role of climate and human activities. The Holocene 21:651-665. http://dx.doi.org/10.1177/0959683610391320.

Giguet-Covex, C. Gentile Ficetola, F. Fouinat, L., Bajard, M., Gielly, L., Walsh, K., Mocci, F., Develle, A.-L., Brisset, E., Arnaud, F., Poulenard, J., 2015. Histoire de l'agriculture dans les Alpes françaises: un nouveau regard fournit par l'ADN sédimentaire lacustre. 15ème Congrès français de sédimentologie.

Gobet, E., Tinner, W., Hochuli, P.A., van Leeuwen, J.F.N., Ammann, B., 2003. Middle to Late Holocene vegetation history of the Upper Engadine (Swiss Alps): the role of man and fire. Veg. Hist. Archaeobotany 12:143-163. http://dx.doi.org/10.1007/s00334-003-0017-4.

Grieve, I.C., 2001. Human impacts on soil properties and their implications for the sensitivity of soil systems in Scotland. CATENA 42:361-374. http://dx.doi.org/10.1016/S03418162(00)00147-8

Harrison, A., Bocock, K., 1981. Estimation of soil bulk-density from loss-on-ignition values. J. Appl. Ecol. 919-927.

Heiri, O., Lotter, A.F., Lemcke, G., 2001. Loss on ignition as a method for estimating organic and carbonate content in sediments: reproducibility and comparability of results. J. Paleolimnol. $25,101-110$

Huggett, R., 1998. Soil chronosequences, soil development, and soil evolution: a critical review. Catena 32, 155-172.

Jäger, H., Achermann, M., Waroszewski, J., Kabała, C., Malkiewicz, M., Gärtner, H., Dahms, D., Krebs, R., Egli, M., 2015. Pre-alpine mire sediments as a mirror of erosion, soil formation and landscape evolution during the last $45 \mathrm{ka}$. Catena 128:63-79. http://dx.doi.org/10. 1016/j.catena.2015.01.018

Jenny, H., 1941. Factors of Soil Formation-A System of Quantitative Pedology. McGraw-Hill, New York

Le Roy, M., Nicolussi, K., Deline, P., Astrade, L., Edouard, J.-L., Miramont, C., Arnaud, F., 2015. Calendar-dated glacier variations in the western European Alps during the Neoglacial: the Mer de Glace record, Mont Blanc massif. Quat. Sci. Rev. 108:1-22. http://dx.doi.org/ 10.1016/j.quascirev.2014.10.033.

Legros, J.-P., 2007. Les grands sols du monde. PPUR presses polytechniques

Li, L., Du, S., Wu, L., Liu, G., 2009. An overview of soil loss tolerance. Catena 78:93-99. http://dx. doi.org/10.1016/j.catena.2009.03.007.

Martin, L., Jacomet, S., Thiebault, S., 2008. Plant economy during the Neolithic in a mountain context: the case of "Le Chenet des Pierres" in the French Alps (Bozel-Savoie, France). Veg. Hist. Archaeobotany 17:113-122. http://dx.doi.org/10.1007/s00334-008-0191-5.

Massa, C., Bichet, V., Gauthier, É., Perren, B.B., Mathieu, O., Petit, C., Monna, F., Giraudeau, J., Losno, R., Richard, H., 2012. A 2500 year record of natural and anthropogenic soil erosion in South Greenland. Quat. Sci. Rev. 32:119-130. http://dx.doi.org/10.1016/j.quascirev. 2011.11.014.

Matson, P.A., 1997. Agricultural intensification and ecosystem properties. Science 277:504-509. http://dx.doi.org/10.1126/science.277.5325.504.

Montagne, D., Cousin, I., Cornu, S., 2016. Changes in the pathway and the intensity of albic material genesis: role of agricultural practices. Geoderma 268:156-164. http://dx.doi.org/10. 1016/j.geoderma.2016.01.019.

Mourier, B., Poulenard, J., Carcaillet, C., Williamson, D., 2010. Soil evolution and subalpine ecosystem changes in the French Alps inferred from geochemical analysis of lacustrine sediments. J. Paleolimnol. 44:571-587. http://dx.doi.org/10.1007/s10933-010-9438-0.

Mouthon, F., 2009. Les Bauges médiévales. Université de Savoie, Chambéry .

Munsell Color, C., 2000. Munsell soil color charts. Gretabacbeth

Nasri, B., Fouché, O., Torri, D., 2015. Coupling published pedotransfer functions for the estimation of bulk density and saturated hydraulic conductivity in stony soils. Catena 131: 99-108. http://dx.doi.org/10.1016/j.catena.2015.03.018.

Pallmann, H., 1947. Pédologie et Phytosociologie. Comptes rendus de la Conférence de Pédologie Méditerranéenne. Springer, pp. 3-36 (Editions AFES).

Paroissien, J-B., Darboux, F. Couturier, A., Devillers, B, Mouillot, F. Raclot, D. Le Bissonnais, Y, 2015. A method for modeling the effects of climate and land use changes on erosion and sustainability of soil in a Mediterranean watershed (Languedoc, France). J. Environ. Manag. 150:57-68. http://dx.doi.org/10.1016/j.jenvman.2014.10.034.

Pimentel, D., 2006. Soil erosion: a food and environmental threat. Environ. Dev. Sustain. 8: 119-137. http://dx.doi.org/10.1007/s10668-005-1262-8.

Saenger, A., Cécillon, L., Sebag, D., Brun, J.-J., 2013. Soil organic carbon quantity, chemistry and thermal stability in a mountainous landscape: a Rock-Eval pyrolysis survey. Org. Geochem. 54:101-114. http://dx.doi.org/10.1016/j.orggeochem.2012.10.008.

Saenger, A., Cécillon, L., Poulenard, J., Bureau, F., De Daniéli, S., Gonzalez, J.-M., Brun, J.-J., 2015 Surveying the carbon pools of mountain soils: a comparison of physical fractionation and 
Rock-Eval pyrolysis. Geoderma 241-242:279-288. http://dx doi.org/10.1016/j.geoderma. 2014.12.001.

Shand, C.A., Wendler, R., 2014. Portable X-ray fluorescence analysis of mineral and organic soils and the influence of organic matter. J. Geochem. Explor. 143:31-42. http://dx.doi.org/10. 1016/j.gexplo.2014.03.005.

Talbot, M., 1988. The origins of lacustrine oil source rocks: evidence from the lakes of tropical Africa. London, Special Publications]->Geol. Soc. Lond., Spec. Publ. 40, 29-43.

ten Broeke, G.A., van Voorn, G.A.K., Kooi, B.W., Molenaar, J., 2016. Detecting tipping points in ecological models with sensitivity analysis. Math. Model. Nat. Phenom. 11:47-72. http:// dx.doi.org/10.1051/mmnp/201611405.

Valese, E., Conedera, M., Held, A.C., Ascoli, D., 2014. Fire, humans and landscape in the European Alpine region during the Holocene. Anthropocene 6:63-74. http://dx.doi.org/10.1016/j. ancene.2014.06.006.

Vanmaercke, M., Poesen, J., Govers, G., Verstraeten, G., 2015. Quantifying human impacts on catchment sediment yield: a continental approach. Glob. Planet. Chang. 130:22-36 http://dx.doi.org/10.1016/j.gloplacha.2015.04.001.

Verheijen, F.G.A., Jones, R.J.A., Rickson, R.J., Smith, C.J., 2009. Tolerable versus actual soil erosion rates in Europe. Earth Sci. Rev. 94:23-38. http://dx.doi.org/10.1016/j.earscirev.2009.02.003.

Verstraeten, G., Poesen, J., 2002. Using sediment deposits in small ponds to quantify sediment yield from small catchments: possibilities and limitations. Earth Surf. Process. Landf. 27: 1425-1439. http://dx.doi.org/10.1002/esp.439.
Waters, CN Zalasiewicz J Summerhayes, C Barnosky, A.D Poirier, C Ga uszka, A Cearreta, A., Edgeworth, M., Ellis, E.C., Ellis, M., Jeandel, C., Leinfelder, R., McNeill, J.R., Richter, D.d., Steffen, W., Syvitski, J., Vidas, D., Wagreich, M., Williams, M., Zhisheng, A., Grinevald, J., Odada, E., Oreskes, N., Wolfe, A.P., 2016. The Anthropocene is functionally and stratigraphically distinct from the Holocene. Science 351. http://dx.doi.org/10.1126/ science.aad2622 (aad2622-aad2622).

Wilkinson, B.H., 2005. Humans as geologic agents: a deep-time perspective. Geology 33 161-164.

WRB - FAO, 2014. World Reference Base for Soil Resources 2014 International Soil Classification System for Naming Soils and Creating Legends for Soil Maps. FAO, Rome .

Zamolo, G., 1980. Régime des eaux souterraines dans les massifs calcaires: hydrogéologie du secteur sud-est du massif des Bauges (Savoie), bassins versants du Ternèze et du Nant d'Aillon-Alpes françaises. Université Scientifique et Médicale de Grenoble .

Zinke, P., Stangenberger, A., Post, W., Emanual, W., Olson, J., 1986. Worldwide Organic Soil Carbon and Nitrogen Data NDP-018 Carbon Dioxide Inf. Cent., Oak Ridge Natl. Lab., Oak Ridge, Tenn.

Zolitschka, B., 1998. A 14,000 year sediment yield record from western Germany based on annually laminated lake sediments. Geomorphology 22, 1-17. 